\title{
Australian Journal of Crop Science
}

\section{Germination and morphology of seeds and seedlings of Colubrina glandulosa Perkins after overcoming dormancy}

\author{
João Luciano de Andrade Melo Junior*, Luan Danilo Ferreira de Andrade Melo, João Correia de Araújo \\ Neto, Vilma Marques Ferreira
}

\author{
Department of Plant science, Center of Agricultural Sciences, Federal University of Alagoas, Rio Largo, AL, Brazil
}

\author{
*Corresponding author: luciiano.andrade@yahoo.com.br
}

\begin{abstract}
The objectives of the present study were to morphologically characterize the seeds, study post-seminal development, and report the best treatment to overcoming dormancy of colubrina (Colubrina glandulosa Perkins). Eight replicates of 100 seeds were weighed and the length, width, and thickness of each seed were measured for the physical characterization. External and internal aspects were considered for the morphological description of the seeds. Seven pre-germination treatments were used to overcoming dormancy: $\left(T_{1}\right)$ intact seeds; immersion in sulfuric acid for $60\left(T_{2}\right)$ and $90 \mathrm{~min}\left(\mathrm{~T}_{3}\right) ;\left(\mathrm{T}_{4}\right)$ manual scarification in the region opposite the hilum; $\left(\mathrm{T}_{5}\right)$ immersion in water at $80^{\circ} \mathrm{C}$, followed by standing in the same water outside the heat for 24 hours at room temperature; and immersion in distilled water for $24\left(T_{6}\right)$ and 48 hours $\left(T_{7}\right)$. The germinative process was recorded for 19 days in the post-seminal study. The variables analyzed were germination, first count, speed, average germination time, germination uncertainty and synchrony, seedling length, and dry mass. This was a completely randomized designed study, with four replicates of 25 seeds in each treatment. The seeds were morphologically highly variable. The testal and the embryo were the invaginated type. Germination was epigeal and the phanerocotyledonal type. Manual scarification induced maximum germinability in the mean time, resulting in a unimodal distribution of the relative frequency and high synchronization of germination, which allowed for the maximum number of highly vigorous seedlings. These results indicate a treatment for overcoming dormancy in C. glandulosa.
\end{abstract}

Keywords: Colubrina; Morphological description; Physical Characterization; Post-seminal study; Pre-germination treatments. Abbreviations: As_Pearson's asymmetry coefficient; ca_caruncle; cf_coif; cl_colo; co_cotyledon; COMPPA_aerial part length; COMPR_root length; eo_eophile; ep_epicotyl; fh_hilar slit; ga_axillary buds; GER_germination; hp_hypocotyl; hp-r_hypocotylradicle; IVG_index of germination speed; m_mean; md_median; $\mathrm{m}_{0 \_}$mode; MSPA_aerial part dry mass; MSR_root dry mass; pc_petiole; PCG_first germination count; pf_foliar primordia; ph_hilar tip; pl_plumule; rp_primary root; rs_secondary root; tg_integument; TMG_average germination time; ts_forehead; U_uncertainty index; VMG_average speed of germination; Z_synchronicity index.

\section{Introduction}

Colubrina glandulosa Perkins (Rhamnaceae), commonly known as colubrina, is a native species that occurs from the eastern coast of Brazil to Paraguay and Peru. It grows rapidly, produces wood, and is being widely used to restore degraded areas. Colubrina is a recommended species for landscaping and afforestation of public squares (Lorenzi, 2016). The seeds of the plant are markedly impermeable to water (Carvalho, 2005), making germination slow and uneven.

Although it is a multiple-use species with great potential in mixed reforestation programs, the procedures for conducting germination tests are not yet standardized by the Rules for Seed Analysis (Brasil, 2009), the Instructions for Analysis of Seeds of Forest Species (Brasil, 2013), and publications that standardize the methodology of germination tests, including recommendations for pregerminative treatments, proper substrates, the amount of water in the substrate, and the temperature to be used.
Aspects of colubrina germination and the morphological characteristics of the fruits, seeds and seedlings are scarce in the literature. Information on morphology and the stages of post-seminal development aid in interpreting and standardizing germination tests. According to Baskin and Baskin (2014), these data are essential for identifying species and to understand the mechanisms of natural dispersion, succession, and regeneration, as well as for phylogenetic and ecological purposes.

Cavalheiro et al. (2007) observed an increase in the mean germination time when attempting to overcome dormancy in colubrina seeds, whereas Garcia et al. (2009) reported a reduced percentage of seed germination, which reinforced the need for new tests, especially in seeds from warmer regions, such as those prevalent in northeast Brazil. It is noteworthy that no study has associated the dynamics of germination with this species' morphology. 
Thus, the present study morphologically characterized the seeds of $C$. glandulosa to study post-seminal development and to report the best treatment to overcome dormancy.

\section{Results and discussion}

\section{Physical analysis of seeds}

The weight of 1,000 seeds, whose water content was $15.9 \%$, was an average of $14.52 \mathrm{~g}$, corresponding to 68,870 seeds $/ \mathrm{kg}$, with a coefficient of variation (CV) of $1.37 \%$ (Table 1 ) of the limit required by the Rules for Seed Analysis (Brasil, 2009), which is a maximum of $4 \%$. This 1,000 seed weight differed from that reported by Garcia et al. (2009) of 58,245 seeds $/ \mathrm{kg}$, indicating that the seeds under study were smaller and lighter than those used by these authors, probably due to climate differences between regions and the origin of the seeds of different matrices. The initial water content of the seeds used by Garcia et al. (2009) was $25.6 \%$, which may also explain the observed differences. The difference observed may be associated with the genetic variability between matrices of the same species, as well as age, nutritional status, and the environmental conditions in which each matrix tree was submitted, as these were in different localities and reflect a wide variety of phenotypes (Müller et al., 2017).

The colubrina seeds were irregularly shaped (length, 1.91$5.09 \mathrm{~mm}$ and width, $1.82-4.92 \mathrm{~mm}$ ). Their range in thickness was $1.22-2.75 \mathrm{~mm}$. The length and width dimensions present greater variance and standard deviation in relation to seed thickness, indicating high variation in these characteristics (Table 2).

The frequency histograms and Pearson's asymmetry coefficient indicated a strong negative asymmetric behavior for length, with a shift of the curve to the right of the main peak, and the mode located to the right of the mean and median values $\left(m_{0}>m d>m\right)$; these characteristics indicate a predominance of seeds with longer than average length of 4.11-4.49 mm (Figure 1A). A weak positive asymmetric distribution was detected in seed width, with a shift of the curve to the left; the modal value was located to the left of the median and mean values $\left(m_{0}<m d<m\right)$, indicating that there were seeds with a width below the mean value, predominantly between 2.80 and $3.18 \mathrm{~mm}$ (Figure 1B). The result for thickness was symmetric, coinciding with the mode, median, and average values $\left(m_{0}=m d=m\right)$ and $a$ small variation in this dimension of 1.90 and $2.08 \mathrm{~mm}$ (Figure 1C).

\section{External and internal aspects of seeds}

Seeds of colubrina are liberated by the natural opening of the fruit, ellipsoid in shape, with a bright and smooth forehead, which varied from dark brown to black, covered externally by a thin waxy cuticular layer and was truncated at the hilar tip. The supposed hilar slit is the junction between the hilum and the micropyle, which did not visibly separate these two structures (Figure $2 \mathrm{~A}$ and $\mathrm{B}$ ). A small caruncle was present, which is a fleshy excretion located near the micropillary region; the remaining part of the fruit was curved, narrow, persistent, and light-yellow in color (Figure 2C).
The embryo was well developed, flat, and foliaceous with yellowish cotyledons. A small hypocotyl-radicle axis was present, forming a thick cylinder, which faced the hilar region in an axial position and occupied less than one-third the total length of the seed. The plumule was located above the hypocotyl-radicle axis and was well differentiated with subdivisions into many leaflets. The embryo was of the invaginated type, with a delimitation that was manifested by an emarginated base of the cotyledons or by invagination of the cotyledon axis (Figure 2D).

\section{Stages of germination process}

Seedlings developed in 10 stages, based on the post-seminal study. The first visible manifestations of germination occurred 5 hours after the imbibition/absorption process began and were distinguished by swelling of the seed. The primary root protruded through the hilar tip on day 1 (Figure $3 A)$. On day 2, the cream colored primary root was $4 \mathrm{~mm}$ long (Figure $3 \mathrm{~B}$ ), exhibited positive gravitropism, and was cylindrical in shape. The primary root lengthened on days 3 and 4 and the coif appeared (Figure $3 C$ and D).

The root started to expand on day 5 and was distinguishable from the hypocotyl. The root was a cylindrically shaped and light green in color throughout its extension (Figure 3E).

The base of the hypocotyl, the so-called colo, was dilated on day 6 , which distinguished it from the primary root (Figure 3F). The hypocotyl was whitish in color with hairs in the transition region between the two structures. This region is morphologically consistent in tropical forest species in which it occurs, and, according to Oliveira (1993), may be another element to identify seedlings. The foliar primordia (Figure $3 \mathrm{E}$ and $\mathrm{F}$ ) also became evident at this time with subsequent release of the seed integument (Figure 4A).

The leaves or eophiles were composed of paripinadas by day 7, and the seed was considered germinated by the Rules for Seed Analysis (Brasil, 2009). The long and cylindrical hypocotyl was an average of $56 \mathrm{~mm}$ in length and thickened at the base. The cotyledons at this stage were completely detached from the integument and were expanding. They were situated opposite and were sessile and very delicate; a coriaceous consistency, glabrous, oblong; with a rounded apex and base; and initially dark green in color; the leaves were inserted into the cotyledonary nodes by means of short petioles (Figure $4 \mathrm{~A}$ and $\mathrm{B}$ ). This behavior characterizes germination of the epigeal type and phanerocotonous seedlings (Ducke, 1965).

Carvalho (2005) reported that adult colubrina plants have simple leaves, and the heterofilia phenotype was identified, by which leaves with more than one form occur during different periods of development.

The petioles and cotyledons were stretched on day 10 when the first secondary roots appeared (Figure 4B). New axillary buds, more developed secondary roots, and senescence signs of the cotyledons were observed on day 14. The main root had reached an average length of $23 \mathrm{~mm}$ by this time (Figure $4 \mathrm{C}$ ).

The cotyledons began to fall off on day 19. The hypocotyl and the primary root reached mean lengths of 99 and 34 $\mathrm{mm}$, respectively, and the epicotyl was already quite developed at $30-40 \mathrm{~mm}$ of length. The fully formed first- 
Table 1. Descriptive statistics of weighings (100 seeds per replicate) obtained for the calculation of the weight of one thousand seeds of $C$. glandulosa.

\begin{tabular}{lc}
\hline Statistical measures & Weight of one thousand seeds \\
\hline Mean $(\mathrm{g})$ & 1.452000 \\
Variance $\left(\mathrm{S}^{2}\right)$ & 0.000398 \\
Standard deviation $(\mathrm{S})$ & 0.019950 \\
\hline $\mathrm{CV}(\%)$ & 1.37 \\
\hline
\end{tabular}
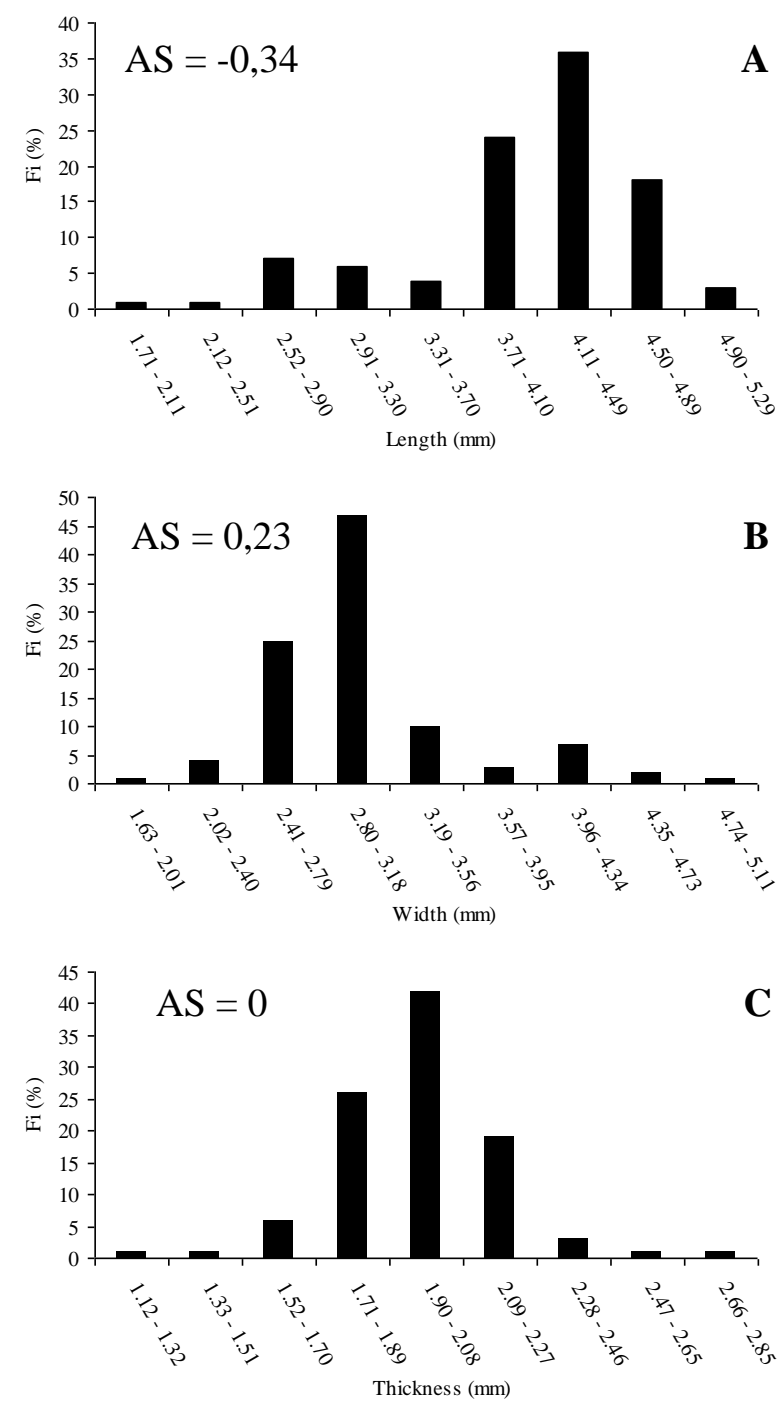

Fig 1. Distribution of the relative frequency (Fi) of the length (A), width (B) and thickness (C) of C. glandulosa seeds.

Table 2. Descriptive statistics of the length, width and thickness of $C$. glandulosa seeds.

\begin{tabular}{lccc}
\hline Statistical measures & Length $(\mathrm{mm})$ & Width $(\mathrm{mm})$ & Thickness $(\mathrm{mm})$ \\
\hline Mean & 4.05 & 3.05 & 1.97 \\
Mode & 4.25 & 2.93 & 1.97 \\
Median & 4.16 & 2.94 & 1.97 \\
Variance & 0.35 & 0.28 & 0.04 \\
Standard deviation & 0.59 & 0.53 & 0.19 \\
Range of variation & 3.18 & 3.10 & 1.53 \\
\hline CV (\%) & 14.54 & 17.31 & 9.89 \\
\hline
\end{tabular}


D

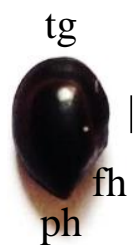

A

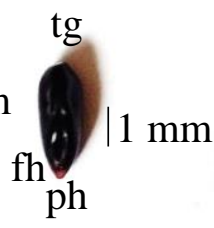

B

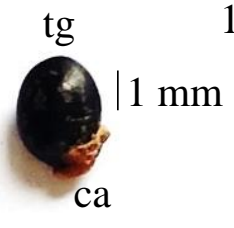

C

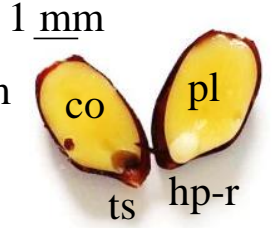

ts

Fig 2. Morphological characterization of C. glandulosa seeds. A - C: external aspects. D: internal aspects. Legend: ca - caruncle; co cotyledon; fh - hilar slit; hp-r - hypocotyl-radicle; ph - hilar tip; pl - plumule; tg - integument; ts - forehead.

Table 3. Germination (GER), first germination count (PCG), index of germination speed (IVG) and average germination time (TMG) of $C$. glandulosa seeds, submitted to treatments to overcome dormancy.

\begin{tabular}{lcccc}
\hline Treatments & GER (\%) & PCG (\%) & IVG & TMG (days) \\
\hline Intact seeds & $32 \mathrm{e}$ & $0 \mathrm{~d}$ & $1.200 \mathrm{e}$ & $7.0 \mathrm{c}$ \\
$\mathrm{H}_{2} \mathrm{SO}_{4} / 60 \mathrm{~min}$ & $77 \mathrm{~b}$ & $37 \mathrm{~b}$ & $5.124 \mathrm{~b}$ & $4.1 \mathrm{e}$ \\
$\mathrm{H}_{2} \mathrm{SO}_{4} / 90 \mathrm{~min}$ & $53 \mathrm{c}$ & $0 \mathrm{~d}$ & $2.268 \mathrm{c}$ & $6.3 \mathrm{~d}$ \\
$\mathrm{Manual}$ & $100 \mathrm{a}$ & $65 \mathrm{a}$ & $7.366 \mathrm{a}$ & $3.5 \mathrm{f}$ \\
$\mathrm{H}_{2} \mathrm{O} 80^{\circ} \mathrm{C} / 24 \mathrm{~h}$ & $44 \mathrm{~d}$ & $4 \mathrm{~cd}$ & $1.767 \mathrm{~d}$ & $7.2 \mathrm{c}$ \\
$\mathrm{H}_{2} \mathrm{O} / 24 \mathrm{~h}$ & $43 \mathrm{~d}$ & $5 \mathrm{c}$ & $1.539 \mathrm{~d}$ & $8.0 \mathrm{~b}$ \\
$\mathrm{H}_{2} \mathrm{O} / 48 \mathrm{~h}$ & $38 \mathrm{de}$ & $0 \mathrm{~d}$ & $1.064 \mathrm{e}$ & $9.3 \mathrm{a}$ \\
\hline Value of "F" & $340.11^{* *}$ & $797.76^{* *}$ & $1328.06^{* *}$ & $1302.32^{* *}$ \\
$\mathrm{CV}(\%)$ & 4.80 & 11.35 & 4.54 & 1.76 \\
\hline
\end{tabular}

Means followed by the same lowercase letter in the column do not differ from each other to a $5 \%$ probability by the Tukey test. ** Significant at the $1 \%$ probability level.

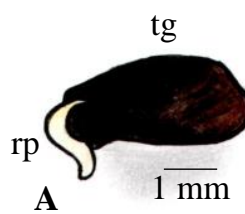

A

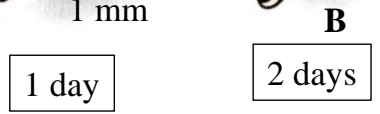

$10 \mathrm{~mm}$

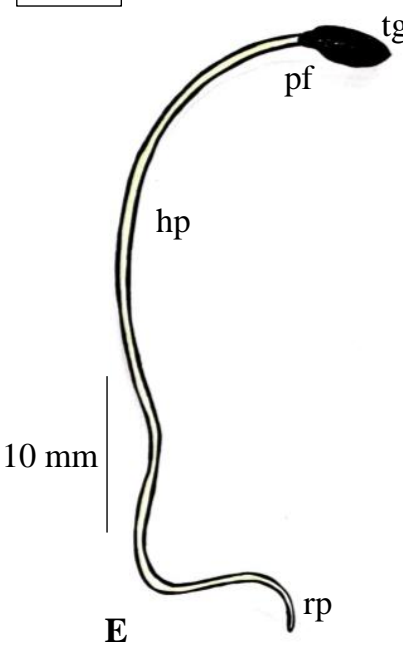

5 days

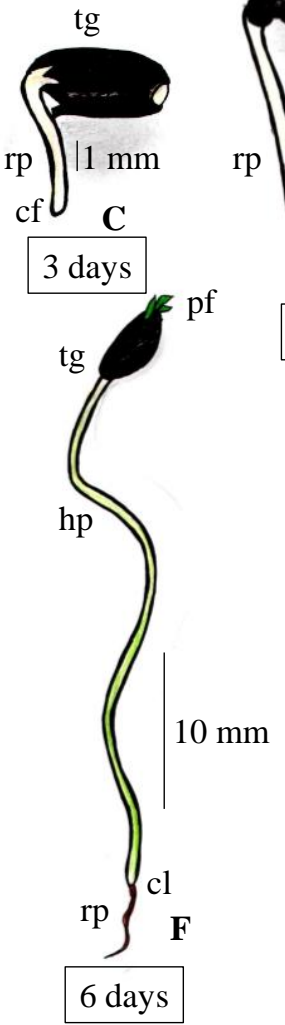

$\operatorname{tg} \mathbf{D}$

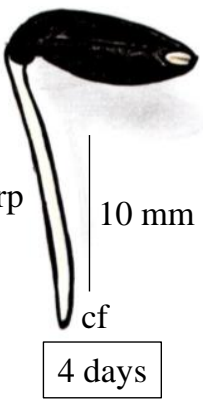

4 days

Fig 3. Germinating process of C. glandulosa from one to six days. A - B: primary root protrusion. C - D: elongation of the primary root, evidencing the coif. E: distinction between the hypocotyl and the primary root. F: dilation at the base of the hypocotyl, called the colo. Legend: $\mathrm{cf}$ - coif; $\mathrm{cl}$ - colo; hp - hypocotyl; pf - foliar primordia; $\mathrm{rp}$ - primary root; tg - integument. 
Table 4. Average speed of germination (VMG), uncertainty index (U) and synchronicity index (Z) of C. glandulosa seeds, submitted to treatments to overcome dormancy.

\begin{tabular}{llll}
\hline Treatments & VMG $\left(\right.$ days $\left.^{-1}\right)$ & $\mathrm{U}$ (bits) & $\mathrm{Z}$ \\
\hline Intact seeds & $0.14 \mathrm{~d}$ & $2.5000 \mathrm{a}$ & $0.0714 \mathrm{~d}$ \\
$\mathrm{H}_{2} \mathrm{SO}_{4} / 60 \mathrm{~min}$ & $0.24 \mathrm{~b}$ & $1.9831 \mathrm{c}$ & $0.2728 \mathrm{~b}$ \\
$\mathrm{H}_{2} \mathrm{SO}_{4} / 90 \mathrm{~min}$ & $0.16 \mathrm{c}$ & $2.0909 \mathrm{~b}$ & $0.1979 \mathrm{c}$ \\
$\mathrm{Manual}$ & $0.28 \mathrm{a}$ & $1.3779 \mathrm{f}$ & $0.4566 \mathrm{a}$ \\
$\mathrm{H}_{2} \mathrm{O} 80^{\circ} \mathrm{C} / 24 \mathrm{~h}$ & $0.14 \mathrm{~d}$ & $1.9934 \mathrm{c}$ & $0.2242 \mathrm{c}$ \\
$\mathrm{H}_{2} \mathrm{O} / 24 \mathrm{~h}$ & $0.12 \mathrm{e}$ & $1.7261 \mathrm{e}$ & $0.2705 \mathrm{~b}$ \\
$\mathrm{H}_{2} \mathrm{O} / 48 \mathrm{~h}$ & $0.11 \mathrm{f}$ & $1.8687 \mathrm{~d}$ & $0.2083 \mathrm{c}$ \\
\hline Value of "F" & $1566.00^{* *}$ & $421.68^{* *}$ & $182.31^{* *}$ \\
$\mathrm{CV}(\%)$ & 1.92 & 1.73 & 7.06
\end{tabular}

Means followed by the same lowercase letter in the column do not differ from each other to a $5 \%$ probability by the Tukey test. ${ }^{* *}$ Significant at the $1 \%$ probability level.

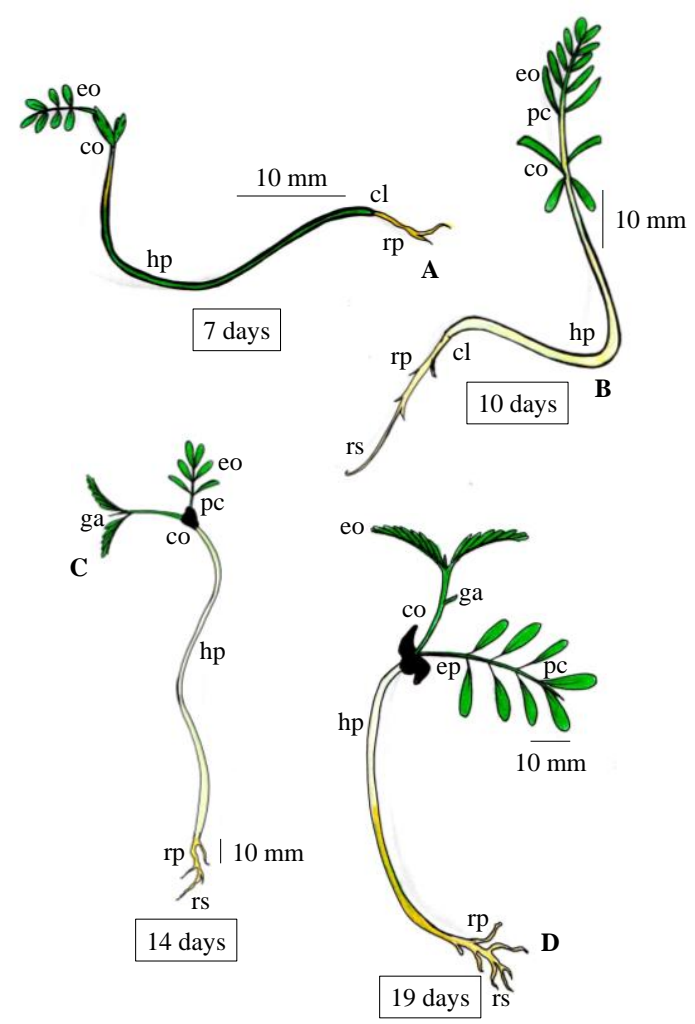

Fig 4. Germination process of $C$. glandulosa from seven to nineteen days. A - B: phanerocotonares seedlings with composite leaves. C: emergence of new axillary buds, more developed secondary roots and signs of cotyledons senescence. D: completely formed first-order eophiles. Legend: $\mathrm{cl}$ - colo; co - cotyledon; eo - eophile; ep - epicotyl; ga - axillary buds; hp - hypocotyl; pc - petiole; rp - primary root; rs - secondary root.

Table 5. Root length (COMPR), aerial part length (COMPPA), root dry mass (MSR) and aerial part dry mass (MSPA) of $C$. glandulosa seedlings, submitted to treatments to overcome dormancy.

\begin{tabular}{lllll}
\hline Treatments & COMPR $(\mathrm{mm})$ & COMPPA $(\mathrm{mm})$ & MSR $(\mathrm{mg})$ & MSPA $(\mathrm{mg})$ \\
\hline Intact seeds & $2 \mathrm{e}$ & $71 \mathrm{c}$ & $1 \mathrm{f}$ & $25 \mathrm{~d}$ \\
$\mathrm{H}_{2} \mathrm{SO}_{4} / 60 \mathrm{~min}$ & $23 \mathrm{~b}$ & $92 \mathrm{~b}$ & $17 \mathrm{~b}$ & $83 \mathrm{~b}$ \\
$\mathrm{H}_{2} \mathrm{SO}_{4} / 90 \mathrm{~min}$ & $14 \mathrm{c}$ & $54 \mathrm{e}$ & $7 \mathrm{c}$ & $36 \mathrm{c}$ \\
$\mathrm{Manual}$ & $29 \mathrm{a}$ & $104 \mathrm{a}$ & $21 \mathrm{a}$ & $91 \mathrm{a}$ \\
$\mathrm{H}_{2} \mathrm{O} 80^{\circ} \mathrm{C} / 24 \mathrm{~h}$ & $14 \mathrm{c}$ & $61 \mathrm{~d}$ & $6 \mathrm{~cd}$ & $30 \mathrm{~d}$ \\
$\mathrm{H}_{2} \mathrm{O} / 24 \mathrm{~h}$ & $12 \mathrm{c}$ & $59 \mathrm{~d}$ & $4 \mathrm{de}$ & $28 \mathrm{~d}$ \\
$\mathrm{H}_{2} \mathrm{O} / 48 \mathrm{~h}$ & $7 \mathrm{~d}$ & $54 \mathrm{e}$ & $2 \mathrm{ef}$ & $26 \mathrm{~d}$ \\
\hline Value of “F” & $158.32^{* *}$ & $417.88^{* *}$ & $256.23^{* *}$ & $523.72^{* *}$ \\
$\mathrm{CV}(\%)$ & 10.09 & 2.74 & 11.14 & 5.41 \\
\hline
\end{tabular}

Means followed by the same lowercase letter in the column do not differ from each other to a $5 \%$ probability by the Tukey test. ${ }^{* *}$ Significant at the $1 \%$ probability level. 
order eophiles were visualized at this time and contained an average of eight leaflets (Figure 4D).

\section{Overcoming dormancy}

The colubrina seeds used in this experiment had a water content of $10.2 \%$. The germinative behaviors of the seeds based on the different treatments used to overcome dormancy are shown in Tables 3-5. Significant differences were observed between treatments for the variables analyzed ( $p \leq 0.05)$.

About $32 \%$ of intact seeds germinated (Table 3 ), indicating that some of the seeds of the population were released from the dormant-free mother plant. This result is similar to that of Garcia et al. (2009) of 31\%, but higher than Cavalheiro et al. (2007) of 7\%, and Brancalion et al. (2011) of 0-10\%, depending on the origin of the lot. These variations in the number of dormant and non-dormant seeds may depend on soil moisture and nutrition, the density of leaves covering the plants, or the degree of environmental disturbance experienced by the population (Baskin et al., 2007; Hoyle et al., 2008; Pinto, 2013). Seeds are released from the mother plant with different degrees of dormancy, a phenomenon called heteroblasty or polymorphism (Marcos-Filho 2015).

We confirmed that the manual scarification treatment in the region opposite the hilum induced the maximum percentage of germinating seeds (Table 3 ). This result corroborates the existence of strong integument dormancy related to seed impermeability to water, and the efficiency of mechanical scarification to overcome it. No other study has used manual scarification in this species.

Physically rupturing of seed coat contributed to increase the permeability to water and gases; thus, benefiting the germination process. A high percentage of germination was also verified in seeds of Piptadenia stipulacea (Benth.) (Farias et al., 2013), Macroptilium martii (Benth.), Maréchal, Baudet (Araújo et al., 2014), and Mimosa ophthalmocentra Mart. ex Benth. by Freitas (2016) subjected to manual scarification treatments. The highest percentages of germination, independent of the harvest year, were for seeds treated with sandpaper and manually scarified.

Manual scarification was adopted in subsequent experiments, as it provided maximum germinability in the fastest time (higher germination speed) (Tables 3 and 4), without impairing seedling development. The speed of germination is associated with the velocity of the water entering the seed, and the consequent activation of metabolic processes. In this case, manual scarification promoted wear on the seed integument, making the soaking and germination processes faster. Standard germination tests should be conducted for this species. Similar results were reported by Benedito et al. (2017), who observed a significant increase in the speed of emergence after manually scarifying seeds of Mimosa tenuiflora Willd.

Notably, immersion in concentrated sulfuric acid for 60 minutes also resulted in rapid germination, although it was statistically inferior to that after manual scarification (Tables 3 and 4). Similarly, there was a directly proportional increase in germination velocity and percentage when Brancalion et al. (2011) used chemical scarification with sulfuric acid for 60 minutes on freshly collected colubrina seeds. Garcia et al. (2009) observed that the best treatments to overcome colubrina seed dormancy were chemical scarification with sulfuric acid and mechanical scarification, and the sulfuric acid treatment accelerated seed germination. Cavalheiro et al. (2007) reported that chemical scarification with sulfuric acid increases the percentage of seeds that germinate; however, mean germination time was not altered. A sulfuric acid treatment that provided $72 \%$ germination produced cracks around the hilar slit and increased porosity of the integument throughout the seed (Pinto, 2013), while increasing imbibition/absorption rates. This observation explains the results obtained in the present study.

Immersion in distilled water at room temperature for 24 and 48 hours and immersion in hot water $\left(80^{\circ} \mathrm{C}\right)$ followed by room temperature water for 24 hours delayed germination. However, there was no reduction in relation to the control (Tables 3 and 4), indicating that the waxy layer of the forehead may have been partially removed, exposing the cells with lignified walls, which allowed the seeds to absorb water and germinate. Garcia et al. (2009) reported that immersion in hot water $\left(100^{\circ} \mathrm{C}\right)$, with the seeds remaining in room temperature water for 8 and 16 hours, reduced the germination percentage compared to the control. Primary root growth was poorly stimulated in these water treatments, and the non-germinated seeds were dead at the end of the test, showing signs of deterioration (softened consistency and unpleasant odor). In addition, fungi attacked the seeds used in these treatments. Imbibition characterizes the beginning of germination and is necessary for the seed to reach an adequate level of hydration, which allows reactivation of metabolic processes, and resumption of embryonic development (Carvalho and Nakagawa, 2012; Bewley et al., 2013).

Table 4 shows the values of uncertainty (informational entropy). Manual scarification resulted in germination frequencies with only a few peaks and a probable unimodal distribution of the relative frequency; that is, the most concentrated germination time. This result shows that a higher level of organization of the process led to a greater speed of germination. Depending on the treatment, the asymmetry of the distribution was heterogeneous due to a majority of slow germinating seeds and a minority of seeds that germinated rapidly (or both). The main mode was not present in the control, and germination of a few seeds appeared scattered over time, with a tendency for a polymodal distribution of the relative frequency. This, together with the autochoric dispersion of the seeds of this species, can be explained by the distribution of colubrina plants in several regions of South America, and the temporal dispersion of seed germination.

Manually scarified seeds showed more homogeneous behavior around the mean and a more synchronized germination time, which was corroborated by the rapid germination of almost all seeds in the first few days. In turn, intact seeds exhibited uneven germination, with low synchronism (Table 4). The uncertainty and synchrony of the germination process are rarely reported by studies of dormancy.

Thus, the presence of physical dormancy, coupled with the large production of small seeds may increase the probability that some seedlings would find favorable conditions in a changing environment, giving a selective advantage to the species (Popinigis, 1977; Labouriau, 1983; Silvertown and Doust, 1993; Ferreira and Borghetti, 2004; Marcos-Filho, 2015). This species displays time distributed germination 
due to the induction of seed dormancy that varies in intensity, which is one of the main mechanisms of species preservation in seed banks (Carmona, 1995; Carvalho and Nakagawa, 2012; Berger et al., 2014). Under natural conditions, these seeds would be part of the soil seed bank. The highest growth of seedlings was observed in the manual scarification treatment (Table 5). In this treatment, seed reserve was entirely devoted to seedling growth, as the germination process was rapid and uniform. This result was justified in subsequent trials, in which seedlings during the seventh stage of development had their cotyledons removed, and all stages in the post-seminal study were reached in 19 days. We verified that the greater seedling growth also favored the accumulation of dry mass (Table 5), resulting in more vigorous seedlings.

\section{Materials and methods}

\section{Plant materials}

The study was conducted at the Plant Propagation Laboratory, Center of Agricultural Sciences, Federal University of Alagoas, Rio Largo, AL, Brazil.

Mature fruit to obtain seeds was harvested from 10 trees belonging to forest fragments located in the municipality of Bom Conselho, PE, located at $09^{\circ} 10^{\prime} 11^{\prime \prime} \mathrm{S}, 36^{\circ} 40^{\prime} 47^{\prime \prime} \mathrm{W}$ and an altitude of 654-m during October-December 2015. The climate is the BSh type in the climatic classification of Köppen, which is semi-arid and hot, according to Emperaire (1984).

The fruits were harvested with aerial scissors and an extensor cable at the end of the maturation period and maintained in a shelter protected from the sun and rain for a few days to complete the drying process and facilitate fruit dehiscence.

The greenhouse method was used at $105 \pm 3^{\circ} \mathrm{C}$ for 24 hours to determine water content of the seeds, according to the requirements of the Rules for Seed Analysis (Brasil, 2009). This determination was made after harvest and at the time the experiments were performed, using two samples of $1 \mathrm{~g}$ each of seeds.

\section{Physical Characterization}

Eight replicates of 100 seeds were used for the physical characterization. The seeds were weighed to verify the weight of 1,000 seeds and the number of seeds/kg (Brasil, 2009). Length, width, and thickness of each seed were measured to obtain the seed dimensions.

We calculated the mean, mode, median, variance, standard deviation, range of variation, and $\mathrm{CV}$ for each variable (Banzatto and Kronka, 2006). The frequencies of the measurements taken from each seed were distributed and grouped into classes for better presentation in the frequency histogram (Labouriau and Valadares, 1976; Labouriau, 1983). Pearson's asymmetry coefficient was calculated to indicate the degree of deviation or departure from the symmetry of a distribution, where $\mathrm{AS}=$ (Average-Mode) $/$ Standard Deviation, using the following scale: $A_{S} \leq-1$ for strong negative asymmetry; $-1<A_{S}<0$ for weak negative asymmetry; $A_{S}=0$ for symmetrical; $0<A_{S}<1$ for weak positive asymmetry; and $A_{S} \geq 1$ for strong positive asymmetry.

\section{Morphological description}

The morphological characterization of the seeds was performed using 25 seeds, which were manually scarified in the region opposite the hilum, and then immersed in distilled water for 5 hours to soften the tegument. They were cut longitudinally and transversally with a scalpel, and the structures were observed under a stereoscope and diagrammed with a clear camera (Corner, 1976). The size, color, locations of the hilum, micropyle, and reserve tissue, as well as the type and location of the embryo and type of germination were analyzed.

\section{Post-seminal study}

Four replicates of 25 seeds were used in the post-seminal study. Germination and the developmental stages of the seedlings were recorded daily for 19 days (Oliveira, 1993). Manually scarified seeds were placed on two sheets of germitest paper to germinate, moistened with distilled water, and placed inside transparent plastic boxes, which were kept in a germinator at $30^{\circ} \mathrm{C}$. The seedlings were removed periodically from the substrate and the structures were measured with a graduated ruler and drawn with the aid of a light chamber, coupled to a stereomicroscope.

\section{Pre-germination treatments}

The seeds were aseptically cleaned by immersion in $70 \%$ alcohol for 1 minute prior to the germination test, followed by washing under running water (Rios et al., 2016). The seeds were placed to germinate on two sheets of previously autoclaved germitest paper, and moistened with a volume of water equivalent to 2.5 times the weight of the substrate (Brasil, 2009) in transparent plastic boxes with a lid (11.0 $\times$ $11.0 \times 3.5 \mathrm{~cm})$. The experiment was conducted in a biological oxygen demand germination chamber at $30^{\circ} \mathrm{C}$ under continuous light, as determined in previous experiments.

The treatments used to overcome dormancy were: $\left(T_{1}\right)$ witness, seeds intact; immersion in $98 \%$ sulfuric acid for 60 $\left(T_{2}\right)$ and 90 minutes $\left(T_{3}\right)$, and then washed in running water; $\left(\mathrm{T}_{4}\right)$ manual scarification with scissors in the region opposite the hilum; $\left(T_{5}\right)$ immersion in water at $80^{\circ} \mathrm{C}$, followed by rest in the same water for 24 hours at room temperature; and immersion in distilled water for $24\left(T_{6}\right)$ and 48 hours $\left(T_{7}\right)$.

The seeds that produced normal seedlings germinated with all their essential structures, showing the potential to continue development and produce normal plants when grown under favorable conditions (Brasil, 2009). The number of seeds that germinated was counted daily at the same time for 19 days, and the substrate was re-wetted when necessary. The variables analyzed were:

Germination: $g i=(\Sigma k i=1 \mathrm{ni} / \mathrm{N}) \times 100$, where $\mathrm{ni}$ is the number of seeds germinated during time $i$ and $\mathrm{N}$ is the total number of seeds placed to germinate (Labouriau, 1983; Carvalho et al., 2005).

First germination count: This count was performed together with the germination test, as the number of normal seedlings on day 3 after the test was initiated.

Index of germination speed: IVG $=G_{1} / N_{1}+G_{2} / N_{2}+\ldots+G_{n} / N_{n}$, where $G_{1}, G_{2}$, and $G_{n}$ are the numbers of seeds germinated in the first, second, and last counts; and $N_{1}, N_{2}$, and $N_{n}$ are 
the numbers of days of sowing at the first, second, and last counts (Maguire, 1962).

Average germination time: $t=\Sigma k i=1(\mathrm{niti}) / \Sigma k i=1 \mathrm{ni}$, where ti is the time from the beginning of the experiment to the $i$ nth observation (days or hours); ni is the number of seeds germinated at time $i$ (corresponding number $i$ nth observation); and $k$ is the last day of germination (Czabator, 1962).

Average speed of germination: $v=1 / t$, where $t$ is mean germination time (Ranal and Santana, 2006).

Relative frequency of germination: $\mathrm{Fi}=\mathrm{ni} / \Sigma k i=1 \mathrm{ni}$, where $\mathrm{ni}$ is the number of seeds germinated per day, and $\Sigma \mathrm{ni}$ is the total number of germinated seeds (Labouriau and Valadares, 1976).

Uncertainty index: $\mathrm{U}=-\Sigma k i=1 \mathrm{Filog} 2 \mathrm{Fi}=\mathrm{Fi}=\mathrm{ni} / \Sigma k i=1 \mathrm{ni}$, where $\mathrm{Fi}$ is the relative frequency of germination; $\mathrm{ni}$ is the number of seeds germinated at time $i$ (corresponding number $i$ nth observation); and $k$ is the last day of germination (Labouriau and Valadares, 1976; Labouriau, 1983).

Synchronicity index: $Z=\Sigma C_{n 1,2} / N=C_{n 1,2}=n i(n i-1) / 2 ; N=$ $\Sigma \mathrm{ni}\left(\sum \mathrm{ni}-1\right) / 2$, where $C_{n 1,2}$ is the combination of germinated seeds in the $i$ nth time and ni is the number of seeds germinated in time $i$ (Primack, 1980).

Length of seedlings: Root length (base of colo to the end of the primary root) and the aerial part (from colo to the apex of the seedling) of normal seedlings were measured at the end of the germination test using a graded ruler.

Dry mass of seedlings: After the measurements, the roots and aerial part of the normal seedlings were packed in Kraft paper bags, placed in a greenhouse with forced air circulating at $80^{\circ} \mathrm{C}$, until constant weight was reached, and their mass was measured on an analytical balance (accuracy of $0.0001 \mathrm{~g}$ ).

The experimental design was completely randomized, with four replicates of 25 seeds per treatment. Data were subjected to analysis of variance, and the means were compared by Tukey's test at the $5 \%$ probability level. The analyses were performed using the SISVAR software 5.6 (Ferreira, 2011). The percentage values were transformed to $\arcsin \mathrm{v} \%$, but the original results are presented in the table.

\section{Conclusion}

The morphology of colubrina seeds was highly variable. The seed was comprised of the testal and an invaginated type embryo. Seed germination was epigeal and the seedlings were phanerocotonares. Manual scarification with scissors in the region opposite the hilum was the best method to overcome dormancy of colubrina seeds, as it resulted in the maximum number of vigorous seedlings.

\section{Acknowledgment}

Corresponding author thanks Coordination for the Improvement of Higher Education Personnel by the granting the scholarship.

\section{References}

Araújo AMS, Torres SB, Nogueira NW, Freitas RMO, Carvalho SMC (2014) Caracterização morfométrica e germinação de sementes de Macroptilium martii Benth. (Fabaceae). Rev Caatinga. 27(3): 124-131.

Araújo Neto JC, Camara CA, Ferreira VM, Lessa BFT, Oliveira YM (2014) Caracterização morfométrica, germinação e conservação de sementes de Caesalpinia pulcherrima (L.) SW. (Fabaceae: Caesalpinioidea). Semin Cien Agrar. 35(4): 2287-2300.

Banzatto DA, Kronka SN (2006) Experimentação agrícola. Jaboticabal, FUNEP, 237p.

Baskin CC, Baskin JM (2014) Seeds: ecology, biogeography, and, evolution of dormancy and germination. San Diego, Academic Press, 1586p.

Baskin CC, Baskin JM, Yoshinaga A (2007) Imbibition and germination of seeds of Colubrina oppositifolia (Rhamnaceae), a Federal-Endangered Tree species endemic to Hawaii. Nat Area J. 27(1): 25-30.

Benedito $\mathrm{CP}$, Ribeiro MCC, Torres SB, Guimarães IP, Oliveira $\mathrm{KJB}$ (2017) Overcome dormancy, temperatures and substrates on germination of Mimosa tenuiflora Willd seeds. Semin Cien Agrar. 38(1): 125-134.

Berger APA, Ranal MA, Santana DG (2014) Variabilidade na dormência relativa dos diásporos de Lithraea molleoides (Vell.) Eng. Ci Fl. 24(2): 1-13.

Bewley JD, Bradford KJ, Hilhorst HWM, Nonogaki H (2013) Seeds: physiology of development, germination and dormancy. New York, Springer, 392p.

Brancalion PHS, Mondo VHV, Novembre ADLC (2011) Escarificação química para a superação da dormência de sementes de saguaraji-vermelho (Colubrina glandulosa Perk. - Rhamnaceae). Rev Árvore. 35(1):119-124.

BRASIL. Ministério da Agricultura, Pecuária e Abastecimento (2013) Instruções para análise de sementes de espécies florestais. Brasília, MAPA/SDA/CGAL, 97p.

BRASIL. Ministério da Agricultura, Pecuária e Abastecimento (2009) Regras para análise de sementes. Brasília, MAPA/ACS, 395p.

Carmona R (1995) Banco de sementes e estabelecimento de plantas daninhas em agroecossistemas. Planta Daninha. 13(1): 3-9.

Carvalho NM, Nakagawa J (2012) Sementes: ciência, tecnologia e produção. Jaboticabal, Funep, 409p.

Carvalho PER (2005) Sobrasil. Colombo, Embrapa Florestas, $10 p$.

Carvalho MP, Santana DG, Ranal MA (2005) Emergência de plântulas de Anacardium humile A. St.-Hil. (Anacardiaceae) avaliada por meio de amostras pequenas. Rev Bras Bot. 28(3): 627-633.

Cavalheiro AL, Pimenta GA, Torezan JMD (2007) Effect of some physical and chemical treatments on germination of Colubrina glandulosa seeds. Seed Sci Technol. 35(3): 744748.

Corner EJH (1976) The seeds of dicotyledons. Cambridge, University Press, 311p.

Czabator FJ (1962) Germination value: an index combining speed and completeness of pine seed germination. Forest Sci. 8(4): 386-396.

Ducke JA (1965) Keys for the identification of seedlings of some prominent woody species in eight forest types in Puerto Rico. Ann Missouri Bot Gard. 52(3): 314-350.

Emperaire L (1984) A região da Serra da Capivara (Sudeste do Piauí) e sua vegetação. Brasil Florestal. 13(60): 5-21. 
Farias RM, Freitas RMO, Nogueira W, Dombroski JLD (2013) Superação de dormência em sementes de jurema-branca (Piptadenia stipulacea). Rev Cienc Agrar. 56(2): 160-165.

Ferreira DF (2011) Sisvar: a computer statistical analysis system. Ciênc Agrotec. 35(6): 1039-1042.

Ferreira AG, Borghetti F (2004) Germinação: do básico ao aplicado. Porto Alegre, Artmed, 323p.

Freitas NWN (2016) Tecnologia de sementes de jurema-deembira (Mimosa ophthalmocentra Mart. ex Benth.). Tese (Doutorado em Agronomia: Área de Concentração em Fitotecnia) - Programa de Pós-graduação em Fitotecnia, Universidade Federal Rural do Semi-Árido, Mossoró, 101p.

Garcia LC, Moraes RP, Sousa SGA (2009) Superação de dormência em sementes de colubrina (Colubrina glandulosa Perk.). Manaus, Embrapa Amazônia Ocidental, $4 \mathrm{p}$.

Hoyle GL, Steadman KJ, Daws MI, Adkins SW (2008) Pre- and post-harvest influences on seed dormancy status of an Australian Goodeniaceae species, Goodenia fascicularis. Ann Bot. 102(1): 93-101.

Labouriau LG (1983) A germinação de sementes. Washington, Secretaria Geral da OEA, 174p.

Labouriau LG, Valadares MEB (1976) On the germination of seeds of Calotropis procera (Ait.) Ait. f. An Acad Bras Ciênc. 48(2): 263-284.

Lorenzi H (2016) Árvores brasileiras: manual de identificação e cultivo de plantas arbóreas nativas do Brasil. Nova Odessa, Plantarum, 384p.

Maguire JD (1962) Seed of germination-aid in selection and evaluation for seedling emergence and vigor. Crop Sci. 2(2): 176-177.
Marcos-Filho J (2015) Fisiologia de sementes de plantas cultivadas. Londrina, ABRATES, 659p.

Müller EM, Gibbert P, Binotto T, Kaiser DK, Bortolini MF (2017) Maturação e dormência em sementes de Peltophorum dubium (Spreng) Taub. de diferentes árvores matrizes. Iheringia Sér Botânica. 71(3): 222-229.

Oliveira EC (1993) Morfologia de plântulas florestais. In: Aguiar IB, Piña-Rodrigues FCM, Figliolia MB. Sementes florestais tropicais, eds. ABRATES, Brasília, pp.175-214.

Pinto TT (2013) Morfoanatomia e fisiologia de sementes com dormência física de Colubrina glandulosa Perkins (Rhamnaceae) e Senna multijuga (Rich.) H. S. Irwin \& Barneby (Caesalpinioideae - Fabaceae). Dissertação (Mestrado em Biologia de Fungos, Algas e Plantas) Programa de Pós-graduação em Biologia Vegetal, Universidade Federal de Santa Catarina, Florianópolis, 71p. Popinigis F (1977) Fisiologia das sementes. Brasília, AGIPLAN, 298p.

Primack RB (1980) Variation in the phenology of natural populations of montane shrubs in New Zealand. J Ecol. 68(3): 849-862.

Ranal MA, Santana DG (2006) How and why to measure the germination process? Rev Bras Bot. 29(1): 1-11.

Rios PAF, Araújo Neto JC, Ferreira VM, Neves MIRS (2016) Seed morphometry and germination of Aechmea costantinii (Mez) L. B. Sm. (Bromeliaceae). Rev Caatinga. 29(1): 85-93.

Silvertown JW, Doust JL (1993) Introduction to plant population biology. London, Blackwell Scientific Publications, 210p. 